\title{
Influence of Climatic Changes and Human Activities on the Salinization Process of Coastal Aquifer Systems
}

\author{
Dimitra Rapti-Caputo* \\ Department of Earth Sciences, University of Ferrara \\ Via G. Saragat 1, 44122 Ferrara, Italy
}

Received: 23 January 2010. Accepted: 23 March 2010.

\begin{abstract}
In the present research, two arid coastal zones of the Mediterranean region (mean annual precipitation about 440 $\mathrm{mm} / \mathrm{a}$ ), have been investigated for evaluating the qualitative and quantitative impact of both human activities and climatic changes on the groundwater resources and the hydrological cycle in general. In particular, the hydrographic network of the Akrotiri (Cyprus) coastal aquifer system is strongly controlled by engineering handicrafts that have induced a quality worsening of the groundwater resources. Due to over-pumping in the central sector of the area, a lowering of the piezometric level of about $15 \mathrm{~m}$ has been observed. As a consequence, a salinization process has occurred in the coastal sector with a mean annual salinization velocity of the salty water front varying between 47 and $97 \mathrm{~cm} / \mathrm{a}$ (period 1964-1996). Due to the high salinity values, the water is at present unsuitable for irrigation use. The second case study is represented by the alluvial plain of Licata (southern Sicily, Italy), where the evolution of the Salso River (in Italian the name means 'Salty River') and the coastal dynamics, characterised by repeated marine transgressions and regressions, qualitatively and quantitatively influenced the underground water resources. Also the anthropogenic activities played a crucial role, especially the farming activity as it is largely documented by the occurrence of numerous greenhouses covering most of the plain. The water depth of the unconfined, mainly sandy, aquifer developed in the Quaternary deposits is between $0.3 \mathrm{~m}$ and locally $5 \mathrm{~m}$ from the surface, while the principal alimentation occurs via infiltration from precipitations and lateral outflow from the Salso River.
\end{abstract}

Key-words: salinization processes, coastal aquifer systems, human activities, climatic changes, Mediterranean region.

\section{Introduction}

During the last decade, the increased exploitation of the underground resources has produced a fast agricultural and socioeconomic development in regions where alternative surface water resources were insufficient. At the world scale, almost $50 \%$ of the population lives within 60 $\mathrm{km}$ from the shoreline (Oude Essink, 2001). In these coastal aquifer systems, when the rate of abstraction and recharge of groundwater quantity are not in balance, a lowering of the groundwater table obviously occurs with the direct consequence of triggering saltwater intrusion phenomena. Among the principal causes of the acceleration of the salt water intrusion processes in the coastal aquifer systems there are: i) the relative sea level rise; ii) coastal erosion phenomena; iii) the variation of the river flow (decrease of the alimentation of the aquifer system along the hydrographic network); iv) human activities (groundwater over-exploration); and v) climatic changes (es. decrease of the precipitation; increase of the evapotranspiration).

In particular as concerns the latter issue, the average surface temperature in the Mediterranean area is expected to increase $0,7-1,6^{\circ} \mathrm{C}$ every $1{ }^{\circ} \mathrm{C}$ of global increase (Mitchell and Hulme, 2000; Palutikof et al., 1996; Cubasch et al., 1996; Barrow et al., 1995; Palutikof and Wigley, 1996; Karas, 1998). According to most prediction models, it is also expected that the precipitation will decrease in several sectors of the Mediterranean area south of $40-45^{\circ} \mathrm{N}$ lati-

* Corresponding Author: Tel.: +39 0532 974688; Fax: +39 0532 974767. E-mail address: cpr@unife.it. 


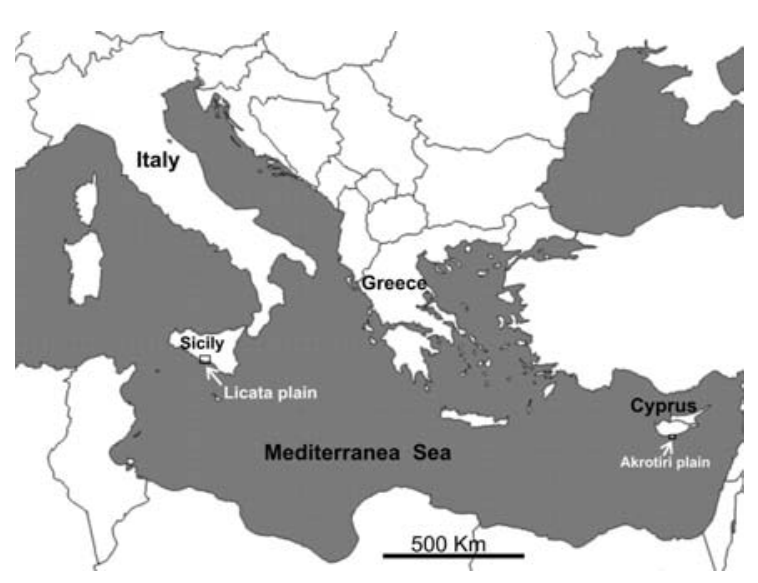

Figure 1. Location of study areas: a) Akrotiri and b) Licata plain (image from Google Earth).

tude and will increase in areas north of $45^{\circ} \mathrm{N}$ latitude (Giorgi and Fransisco, 2000; IPCC, 2001; Palutikof et al., 1996). It is noteworthy that the impact of the climatic changes, which generally lead to increased desertification processes, is known to have affected the Mediterranean arid zone (Sestini et al., 1989; Puigdefàbregas and Mendizabal, 1998; Brandt and Thornes, 1996; Brandt, 2005; Kok et al., 2006; Hill et al., 2008).

At present, many areas of the Mediterranean region are subjected to important processes of salty water intrusion in the aquifer systems (Fig. 1) due to natural, antropogenic causes and/or to other physical factors (UNESCO, 1987; PulidoBosch et al., 1992; Morell et al., 1996; Calvache and Pulido-Bosch, 1997; Dazy et al., 1997; Lambrakis, 1997; Petalas and Diamantis, 1999; Ergil, 2000; Lambrakis and Kallergis, 2001; Tulipano and Fidelibus, 2002; Lozano et al., 2002; Qahman and Larabi, 2006; Kallioras et al., 2006). Particularly in the islands where the available water is generally limited, the salinisation of the underground resources can lead to a severe degradation of the quality characteristics of the water. This fact poses serious environmental, social and economic problems to the local communities of coastal zones.

Once saltwater intrudes into a groundwater body its recovery is nearly impossible even in the long-term. Indeed, artificial recharge of the aquifers or desalination of saltwater are very costly solutions. As a consequence, the need of integrated groundwater resources management in coastal aquifers becomes almost complelling.
At this regards, the determination of the spatial distribution of dominant salinisation processes is crucial for designing adequate groundwater management strategies, since different degradation processes require different remedial and conservation measures.

Accordingly, hydrological, hydrogeological and chemical investigation have been integrated in the analysis of the alluvial coastal aquifer system of Akrotiri (Cyprus) and Licata (Sicily, Italy) for a best evaluation of the influence of the climatic changes and human activities in the hydrological cycle in terms of quantitative impact on the groundwater resources (Fig. 1).

\section{Akrotiri plain}

Cyprus has always been confronted with the problem of limited water resources for domestic and irrigation needs. This is mainly due to a semi-arid climatic regime (average annual rainfall about $500 \mathrm{~mm}$ ) and intensive agriculture activities, but also the recent explosion of the touristic industry caused an additional demand for water. As a consequence, the water shortage in Cyprus started creating a severe problem for the population.

Different coastal aquifer systems of the island present critical salinization problems with electrical conductivity values about 20000 to $30000 \mu \mathrm{S} / \mathrm{cm}$, mainly due to over exploration of the water resources and the low rainfall regime. For example, in the Yermasoyia aquifer near Lemessos the annual extraction is 2.5 times larger than its capacity of active storage. Another illustrative case is represented by the Kokkinochoria area, south of Famagusta, where the demand for groundwater is so large that local lobbies succeeded in making almost ineffective all control measures. It is worthmentioning that among the 8000 borehole detected within the area, about $47 \%$ have been drilled without permission (Fig. 2; Water development Department of Cyprus).

The investigated area considered in this paper is the Akrotiri aquifer system, located at the southernmost sector of the Island of Cyprus. The area varies in elevation from $-2 \mathrm{~m}$ to $30 \mathrm{~m}$ asl and extends for about $45 \mathrm{~km}^{2}$ (Fig. 2). It is one of the most important aquifers of the island 


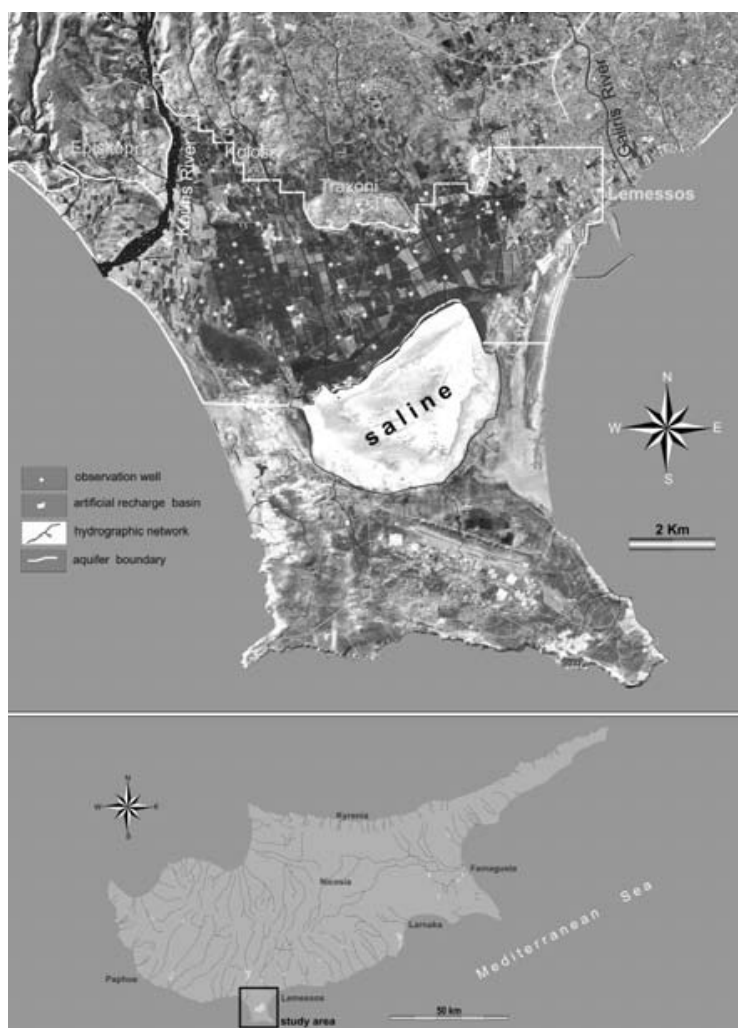

Figure 2. Akrotiri plain: a) investigated area and its location in the southern sector of Cyprus Island (inset); b) water quality observation network (the picture, created by $\mathrm{O}$. Christou (Geoinfo) is a false colour composite image, combination between Landsat TM, KVR 1000 and hill).

because it represents the larger water supply of the town Lemessos, while it is also used for industrial and agricultural purposes (Howard Humphreys \& Sons, 1972). In particular, the aquifer system is bordered to the south by a large Salt Lake, to the east by the Galiris River with drainage area of about $65 \mathrm{~km}^{2}$ and to the west by the Kouris River with a drainage area of $290 \mathrm{~km}^{2}$ (Hydrological Year Book, 1984). The Salt Lake represents a topographic depression with an endorheic drainage, a mean water surface below sea level, though during the summer the lake is completely dry. The Kouris River is the largest river of Cyprus, extending far up into the Troodos Mountains. The average precipitation within its catchment area is 730 $\mathrm{mm}$ for the period 1951-1980.

The study area is characterised by semi-arid to Mediterranean climate, with hot-dry summers and cool-wet winters. Rainfalls are concentrat- ed in the period October to April with mean annual values for the period 1987-1995 of $441 \mathrm{~mm}$.

During the last decade, the increasing need of water related to the strong industrial, agricultural and touristic development caused a qualitative and quantitative degradation of the underground resources. Since 1930 the exploitation of the aquifer system began in concomitance of fruit-tree plantations covering an initial area of about $15 \mathrm{~km}^{2}$ in the central part of the aquifer. In the period 1967-1977, about $14106 \mathrm{~m}^{3} / \mathrm{a}$ of water have been extracted for domestic and irrigation needs, though the first problems associated with the salinization process started manifesting since 1960. Moreover, in 1987, the construction of a dam along the Kouri River reduced the freshwater recharge and consequently accelerated the salinization process of the aquifers in the western sector of the area.

In the early 1990's the Cypriot authorities declared the whole aquifer as a "water conservation area". This implied an authority-controlled groundwater management strategy to prevent further salinization of the aquifer systems. Artificial recharge basins have been created since then and the pumping rate was strongly reduced.

In the present study, numerous samples obtained from several wells drilled all over the study area, have been collected (Fig. 2; T.A.Y. database) and analysed. Following the results of the hydrochemical analyses and the characteristic ionic ratios it was thus possible to recognized the areas with the highest geochemical risk.

\subsection{The aquifer system}

The multi-aquifer system mainly permeates Pliocene-Quaternary deposits consisting of alternating gravel layers, sands, marls and clays characterized by strong lateral and vertical heterogeneity. The thickness of these sediments varies between $5 \mathrm{~m}$, to the northeast, and about $90 \mathrm{~m}$, to the southwest. As a consequence, the permeability of the multi-aquifer system presents strong lateral variations between $10^{-2}$ $\mathrm{m} / \mathrm{sec}$, in the western sector where the coarsegrain sediments of the Kouri River prevail, and $10^{-5} \mathrm{~m} / \mathrm{sec}$, in the eastern sector where fine-grain deposits in contrast prevail.

The alimentation of the aquifers mainly oc- 
curs by infiltration. The mean annual value of natural recharge is about $10 \%$ of the precipitations (Iacovides, 1970; Iacovides et al., 1982) a value compatible with the $49 \mathrm{~mm}$ estimates by Masi et al. (2004), the $61 \mathrm{~mm}$ proposed by Edmunds et al. (1988) for the period 1977-1980 and based on the chloride analyses and the $53 \mathrm{~mm}$ from tritium analyses (Boronina et al., 2005). Other alimentation sources are represented by the Kouris reservoir losses; the lateral inflows from nearby aquifers in the northern sector, agricultural return flows and local artificial recharge from the numerous artificial lakes (T.A.Y. database).

In 1987, the building of a dam along the Kouri River upstream the investigated area strongly reduced the role of the river in feeding the surrounding aquifers, therefore causing important disequilibrium of the parameters within the hydraulic balance. Indeed, before the building of the dam the amount of lateral infiltration from the river towards the aquifers was in the order of $16106 \mathrm{~m}^{3} / \mathrm{a}$, while after the construction of the dam a reduction as high as the $44 \%$ was recorded (Balasha-Jalon consultans, 1992). As a direct consequence, a drastic drop of the piezometric level occurred in the western sector of the coastal plain, therefore accelerating the mixing phenomena with the salty waters. In particular, before the building of the dam, in the western sector of the area, the piezometric level was about $2 \mathrm{~m}$ a.s.l., while negative values $(-5 \mathrm{~m})$ were recorded during the subsequent years when the hydrometric regime of the river was forced.

Furthermore, during the period 1964-1996, due to the large amounts of pumping from the several wells drilled in the central sector of the aquifer, the piezometric level dropped about 15 m with a mean rate of $47 \mathrm{~cm} / \mathrm{a}$. In order to halt the process that began causing severe problems for the agricultural activities, in 1996 a project for the artificial feeding of this area started operating (Fig. 2).

Based on the results of the chemical analyses carried out in October 1995 from samples collected in 68 wells (Fig. 2), the geochemical characterization of the multi-aquifer system was attempted. In order to estimate the pattern of the geochemical parameters of the aquifer, we selected the year 1995 because, firstly, a complete database is available and, secondly, the annual precipitations of that year were similar to the long-term average value.

From the numerous collected samples, the electrical conductivity, the $\mathrm{pH}$ and the TDS were directly measured in situ. Laboratory analyses were carried out for the following parameters: $\mathrm{Ca}, \mathrm{Mg}, \mathrm{Cl}, \mathrm{SO}_{4}, \mathrm{NO}_{3}$ using Cadas 2000 spectrophotometer methods; $\mathrm{K}$ and $\mathrm{Na}$ using atomic adsorption technique; and $\mathrm{HCO}_{3}$ concentration using volumetric methods.

\subsection{Results}

The electrical conductivity (EC) of large sectors of the aquifer shows variations between 700 and $2750 \mu \mathrm{S} / \mathrm{cm}$ (Fig. 3). Low values of this parameter $(700-900 \mu \mathrm{S} / \mathrm{cm})$, which imply a good quality of the underground water resources, are documented along the bed of the Kouri River crossing the central sector of the investigated area. Southeast of the Kouri river (area A), in a $3 \mathrm{~km}$ -

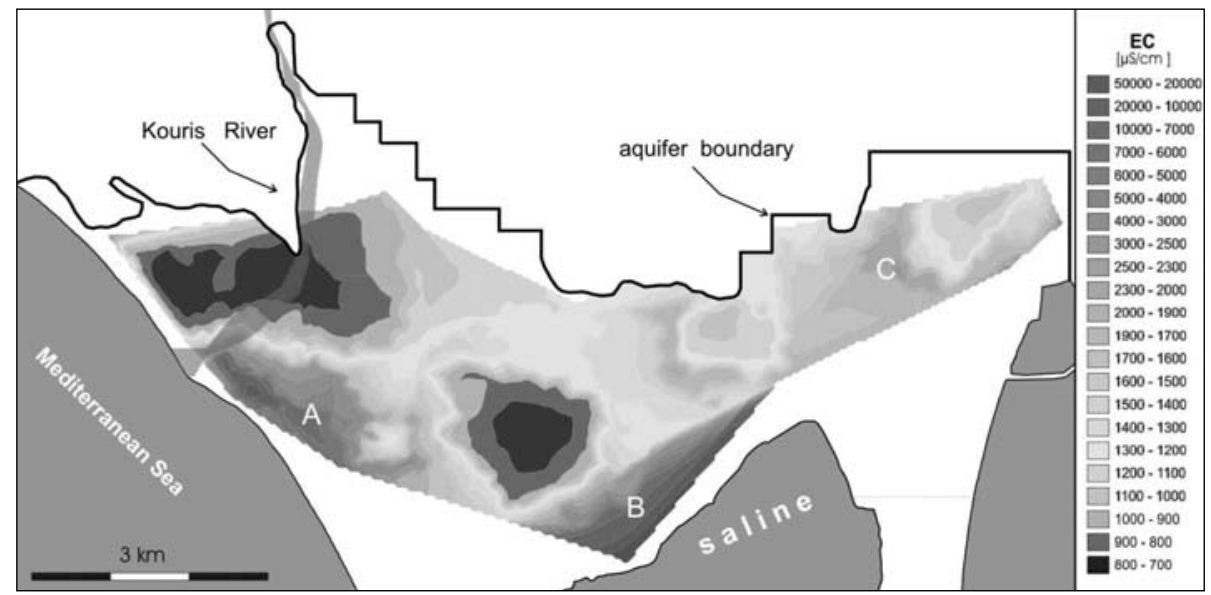

Figure 3. Space distribution of the electrical conductivity $(\mu \mathrm{S} / \mathrm{cm}$ at $25^{\circ} \mathrm{C}$; for the location of the monitored wells see Fig. 2). 


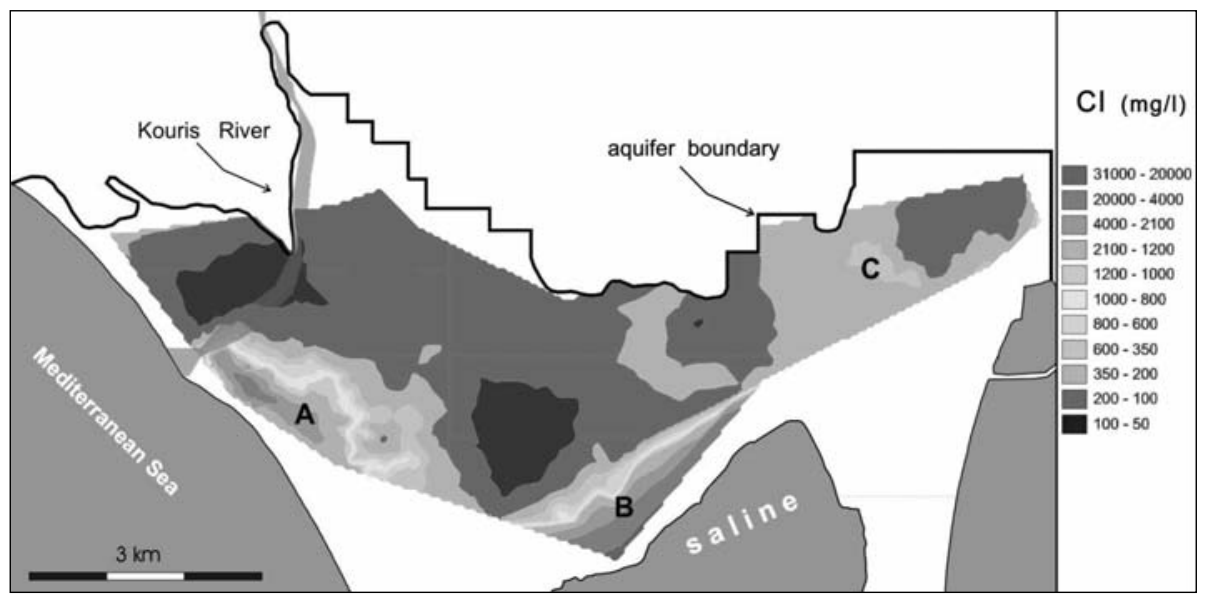

Figure 4. Space distribution of the chloride concentration $(\mathrm{mg} / \mathrm{l}$; for the location of the monitored wells see Fig. 2).

long zone, along the coast and up to a distance of about $1.8 \mathrm{~km}$ from the coast line, the electrical conductivity reaches values as high as 13000 $\mu \mathrm{S} / \mathrm{cm}$. An even higher anomaly (larger 50000 $\mu \mathrm{S} / \mathrm{cm}$ ) has been recorded in a $1.5 \mathrm{~km}$-wide zone of the aquifer along the saline (area B; Fig. 3).

Also these anomalies are confirmed by the high content of chlorides (Fig. 4) and are attributed to mixing phenomena between the fresh water of the aquifer and salty water with different salt content like the marine water, in the first case, and those from the saline, in the second case. In particular, the space distribution of the chlorides shows a trend similar to that of the electrical conductivity. Within the whole aquifer, the chlorides vary between 50 and 350 $\mathrm{mg} / \mathrm{l}$ except areas A and B where the concentration of $\mathrm{Cl}$ is greater than $20000 \mathrm{mg} / \mathrm{l}$.

Eventually, locally high values of the electrical conductivity in the eastern sector, west sec- tor of Lemessos town, are probably caused by urban polluting phenomena (area $\mathrm{C}$ ). The hardness of the water, indicated by the $\mathrm{CaCO}_{3}$ content varies between 190 and $800 \mathrm{mg} / \mathrm{l}$, while values higher than $1500 \mathrm{mg} / \mathrm{l}$ are localised in the south-western sector of the investigated area. Moreover, $\mathrm{Ca}$ and $\mathrm{Mg}$ vary showing values of 17-976 mg/l and 34-2400 mg/l, respectively.

The nitrates, which are mainly associated with the intensive farming activities, present concentrations of 1 to $50 \mathrm{mg} / \mathrm{l}$, with the exception of the areas $\mathrm{A}, \mathrm{B}$ and $\mathrm{C}$ where the concentrations are higher than $400 \mathrm{mg} / \mathrm{l}$ (Fig. 5).

It is well known that from the characteristic ratio of some ions it is possible to infer the provenance of the water and recognize the occurrence of a mixing phenomenon between groundwaters of different geochemical composition (Plummer and Back 1980; Hem 1978; Matthess 1982; Lloyd and Heathcote 1985).

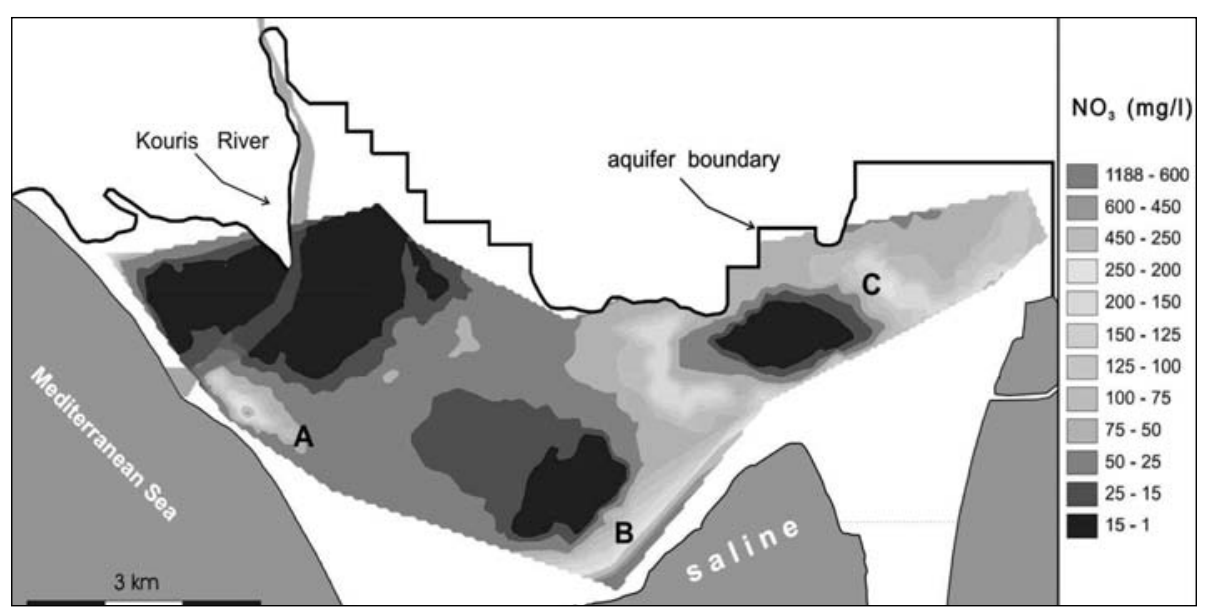

Figure 5. Space distribution of the nitrates $(\mathrm{mg} / \mathrm{l}$; for the location of the monitored wells see Fig. 2). 
Along the coastline, the replacement of fresh water by salty water during the marine ingression is associated with cation exchange processes. In fact, $\mathrm{Ca}$ and $\mathrm{HCO}_{3}$ dominating in the fresh water are replaced by $\mathrm{Na}$ mainly contained in the marine water, therefore generating brackish water dominated by $\mathrm{CaCl}_{2} \quad$ (Back, 1966; Lawrence et al., 1976; Appelo and Geirnaert, 1983). Moreover, a decrease in sulphate concentration is possibly due to the precipitation of gypsum during the first stages of the marine water intrusion (Gomis-Yagues et al., 2000).

In particular, in the Akrotiri aquifer system the $\mathrm{Cl} / \mathrm{HCO}_{3}$ ratio (Revelle index; Revelle, 1941; Fig. 6), shows values larger than 10 in the areas $\mathrm{A}$ and $\mathrm{B}$. In the same areas, we also calculated a higher value of the $\mathrm{Cl} / \mathrm{SO}_{4}$ molar ratio (21-44) that represents an index of the amount of mixing phenomena occurring between fresh and salty waters.
Based on the values and distribution of the electrical conductivity of the waters and the ionic concentrations of $\mathrm{Ca}, \mathrm{Mg}, \mathrm{Na}, \mathrm{SO}_{4}, \mathrm{Cl}$ and $\mathrm{NO}_{3}$ and considering also the limits proposed by the World Health Organisation as concerns the use of the waters for drinking, only the central-western sector of the Akrotiri aquifer is suitable and economically convenient for the exploitation of the underground water resources without requiring long lasting and expensive processes of depuration (Fig. 7).

Because the entire area is prevailingly exploited for agricultural use and most of the water used for irrigation is directly pumped from the underground resources, a particularly useful indicator is the SAR index, which determines the quality of the waters. Accordingly, this index emphasises the occurrence of C2-S3 water category (excellent) in the investigated area with the exception of areas A and B where C4-
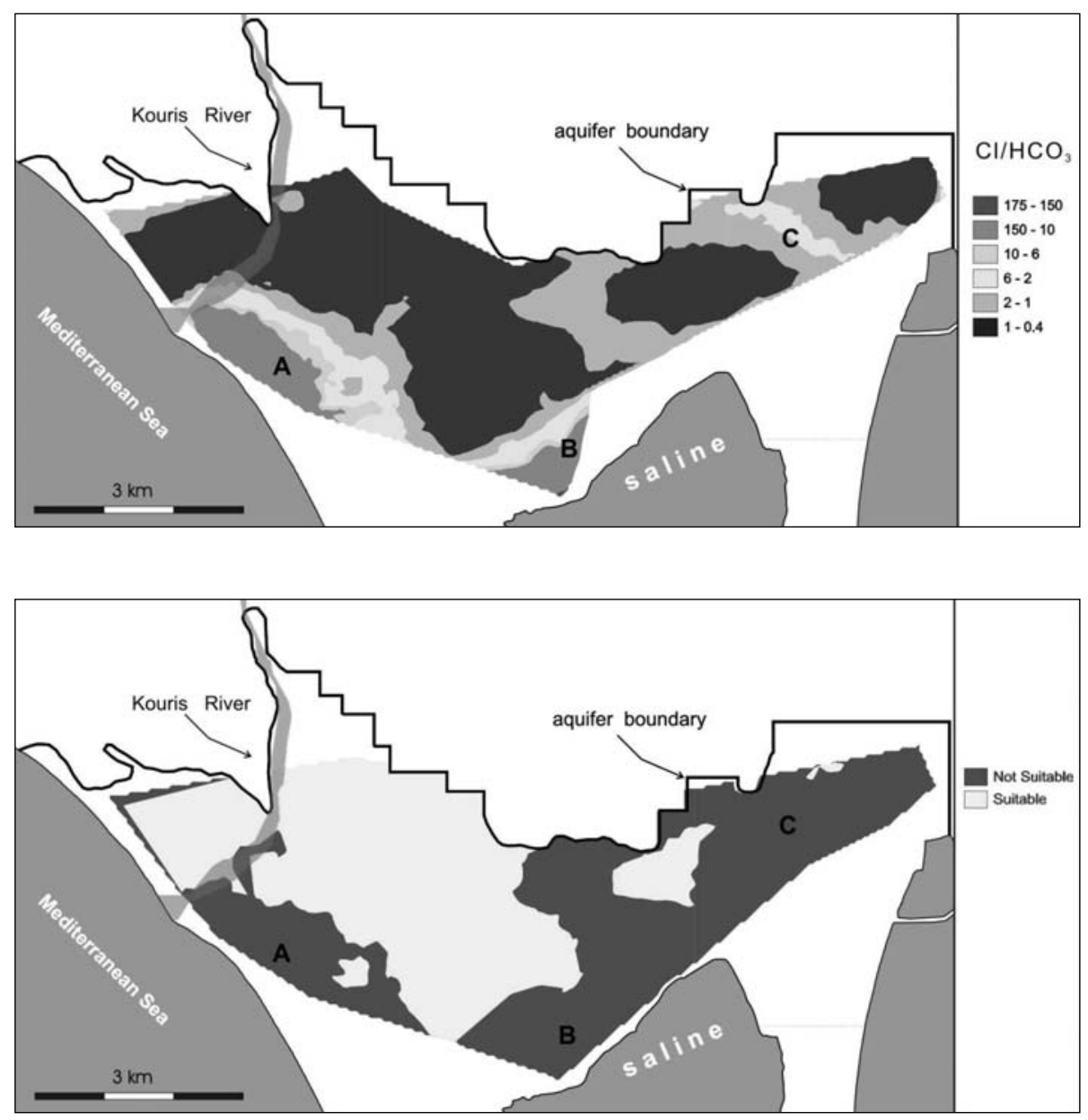

Figure 6. Space distribution of the $\mathrm{Cl} / \mathrm{HCO}_{3}$ ratio (for the location of the monitored wells see Fig. 2).
Figure 7. Water supply suitability map. 


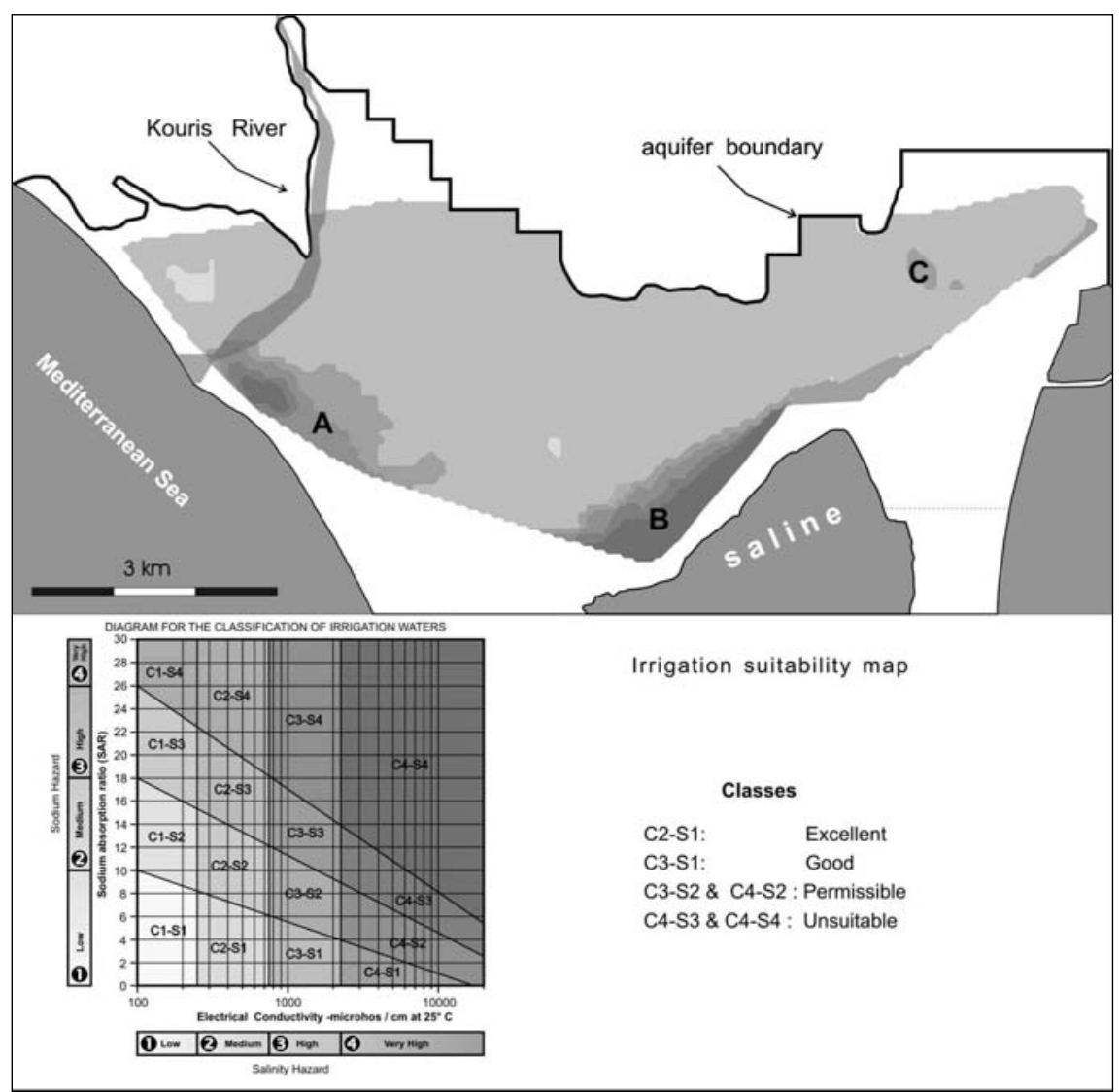

Figure 8. Irrigation suitability map and relative diagram.
S4 water category dominates being not suitable for irrigation purposes (Fig. 8).

\subsection{Consideration}

In the coastal multiaquifer system of Akrotiri and especially in the southwestern sector of the basin (area A), the analysis of the geochemical characteristics of the waters allowed to infer a progressive shift of the fresh-to-salty water interface. Indeed, in the period 1965-1995, marine water ingressed for about $2 \mathrm{~km}$ with a mean velocity of $97 \mathrm{~m} / \mathrm{a}$. This mixing phenomenon between fresh and salty water, probably associated with the alteration of the principal hydraulic parameters of the Kouri River and the increased amount of pumping, is confirmed by the high concentration of $\mathrm{Cl}$ and $\mathrm{Na}$ ions, by the coefficient of Revelle, the electrical conductivity and the $\mathrm{Cl} / \mathrm{SO}_{4}$ ratio.

Moreover, due to the lowering of the piezometric level in the central zone of the basin and the occurrence of sediments characterised by high permeability values, the hydraulic communication between the saline and the multi-aquifer system was certainly enhanced. As a consequence also in the southern sector of the aquifer (area B) an ingression of salty waters was triggered with a mean velocity of about $58 \mathrm{~m} / \mathrm{a}$.

The generally high $\mathrm{NO}_{3}$ concentration is evidently caused by the intense farming of the area, while the few spots with values higher than $200 \mathrm{mg} / \mathrm{l}$ are probably related to local causes. Only the central sector of the study area is characterised by drinkable water which is obviously also exploitable for irrigation purposes as indicated by the low SAR values.

\section{Licata plain}

The first human record within the Licata territory is as old as Late Neolithic. Due to the numerous sulphur mines occurring within the surrounding region, the Licata harbor represented an important trade centre of the Mediterranean till the end of the XX century. The major hydrographic feature of the region is represented by the Southern Imera River, also called Salso 


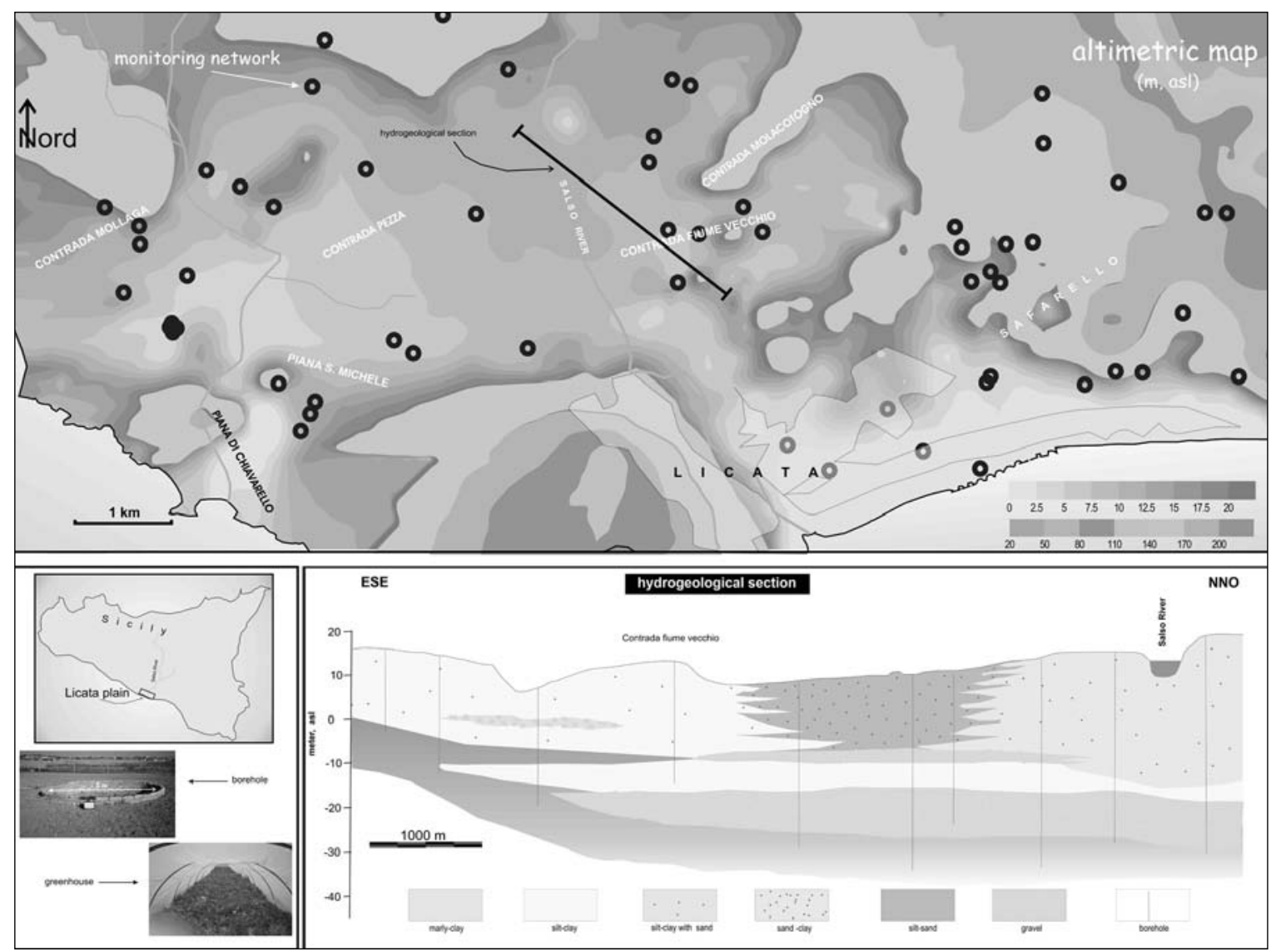

Figure 9. Licata plain: investigated area and its location in the southern sector of Sicily, altimetric model; monitoring network and hydrogeological section.

River, that crosses the plain from north to south (Fig. 9). The natural changes of the river bed, its delta area and the nearby coastal sector, have strongly influenced the evolution of the landscape and produced altimetric variations spanning from 0 to $50 \mathrm{~m}$ above sea level.

According to historical evidences, important phenomena of alternating transgression and retreat of the coastline have occurred in the last centuries (Amore et. al., 2002). This was mainly caused by changes of solid input and the hydrographic evolution of the Salso River bed and secondarily by anthropogenic interventions (eg. artificial reservoirs basins). For example, from 1823 to 1986 is documented a rapid regression with a speed of $3 \mathrm{~m} / \mathrm{a}$, while it further accelerated to $10 \mathrm{~m} / \mathrm{a}$ in the period 1886-1952.

\subsection{The aquifer system}

The Licata plain is largely farmed and almost completely covered by greenhouses, where two productive cycles are carried out every year (autumn-winter and spring-summer), while cultivations need two-three watering per week (Regione Siciliana, 2002). Accordingly, in order to satisfy such a large amount of water resources, several boreholes have been excavated. These wells are commonly of large diameter, up to $5 \mathrm{~m}$, rarely exceeding the $10 \mathrm{~m}$-depth and generally built with stones. They are located both inside and outside the greenhouses (Fig. 9) and exploit an unconfined, or locally semiconfined, aquifer developed within the alluvial deposits of the Salso River. This aquifer mainly consists of sandy or silt-sandy lenses, locally as coarse as gravels, generally 1 to $10 \mathrm{~m}$ thick and hydraulically interconnected (Fig. 9; Rapti-Caputo, 2005).

The feeding sources for the aquifer are mainly two. Firstly, there is the infiltration of the precipitations whose mean annual value is about $454 \mathrm{~mm}$ (1926-2005), showing oscillations between 206 and $1091 \mathrm{~mm}$. Secondly, the aquifer is laterally fed by the Salso River during the 
flooding periods. Indeed, in Italian the word Salso means "salty", thus suggesting that local people was aware of the high salinity of the flowing water. This perception is also clearly documented by measured values of the electrical conductivity as high as 2000 to $14000 \mu \mathrm{S} / \mathrm{cm}$ (at $20{ }^{\circ} \mathrm{C}$ ). These high values are due to the fact that the river largely drains the Messinian evaporitic deposits largely outcropping in the hydrographic basin (the so-called "gessososolfifera" Formation (Roda, 1971).

During May 2005, the water level and the chemico-physical parameters of the water were measured in 45 wells while the ionic concentrations of $\mathrm{Ca}, \mathrm{Mg}, \mathrm{Cl}, \mathrm{SO}_{4}, \mathrm{NO}_{3}$ (using spectrophotometer methods), $\mathrm{K}, \mathrm{Na}$ (using atomic adsorption technique) and $\mathrm{HCO}_{3}$ (using volumetric methods) were subsequently obtained in the laboratory from the collected samples.

\subsection{Results}

The measurements of the depth-to-water show variations between 0.5 and $7 \mathrm{~m}$ (Fig. 10). In par- ticular, the higher depth-to-water values are observed within the central sector of the plain, while the lower ones were measured in the northwestern sector of the plain and east of Licata. The measured values are due to the combined effect of both the lithological and geometric characteristics of the aquifer and the amount of pumping. The contribution of pumping is likely to be minimal because the measurements have been carried out in wells that were not exploited for one day and therefore the aquifer could be considered in stable conditions. The only exception is represented by the bore-hole located west of "Contrada Molacotogno" area, where the measurements were performed with the aquifer in semi-static conditions.

The electrical conductivity of water (measured in situ and referred to $20{ }^{\circ} \mathrm{C}$ ) shows variations between 1 and $12 \mathrm{mS} / \mathrm{cm}$ (Fig. 11). The minimum values of this parameter are observed in the central and western sectors of the plain,
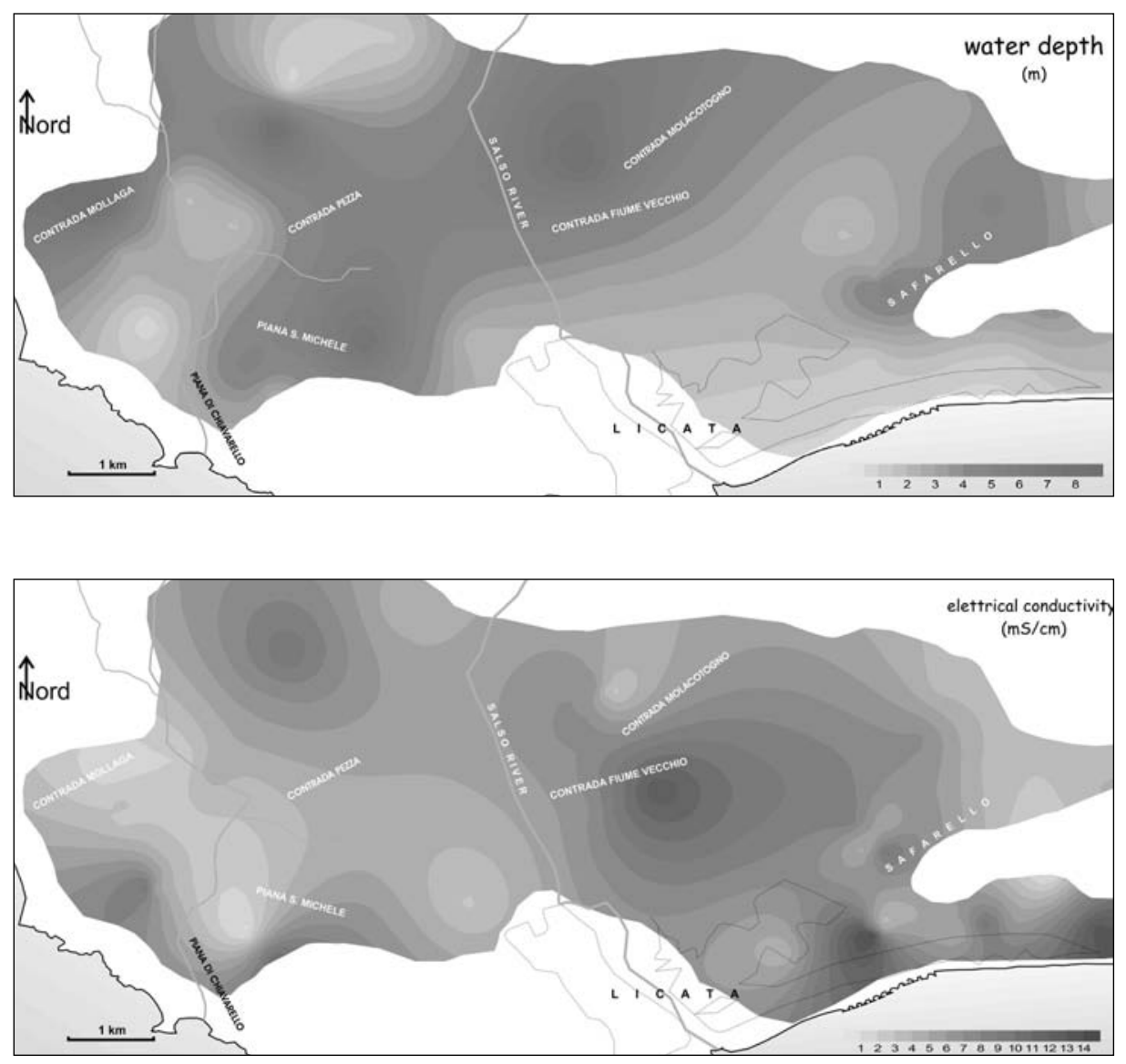

Figure 10. Space distribution of water depth (meter; May 2005; for the location of the monitored wells see Fig. 9).

Figure 11. Space distribution of the electrical conductivity $(\mathrm{mS} / \mathrm{cm}$ at 20 ${ }^{\circ} \mathrm{C}$; for the location of the monitored wells see Fig. 9). 


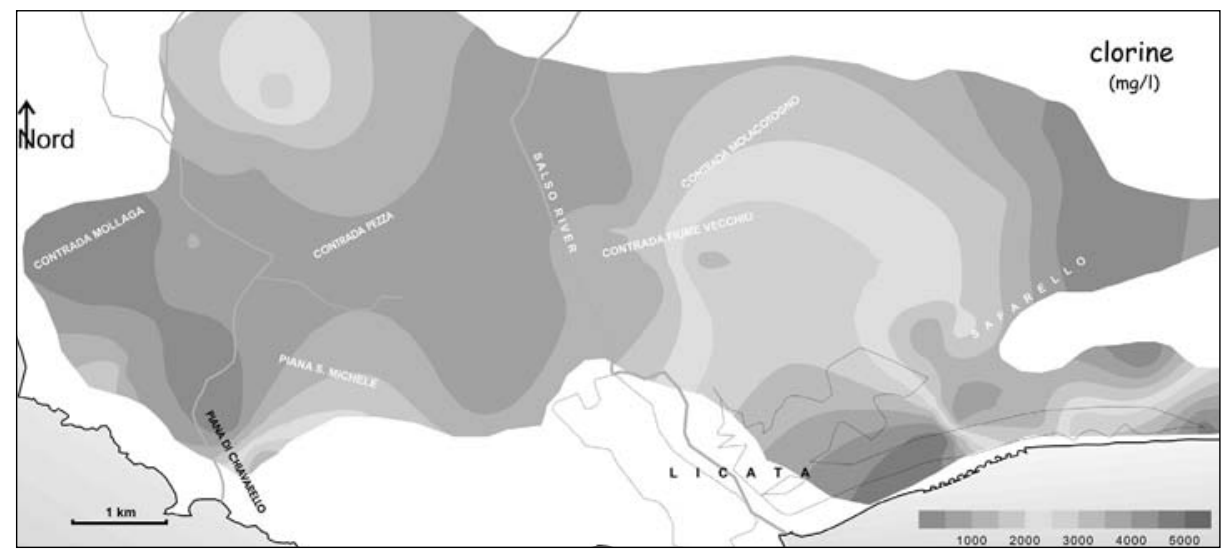

Figure 12. Space distribution of the chloride concentration $(\mathrm{mg} / \mathrm{l}$; for the location of the monitored wells see Fig. 9).

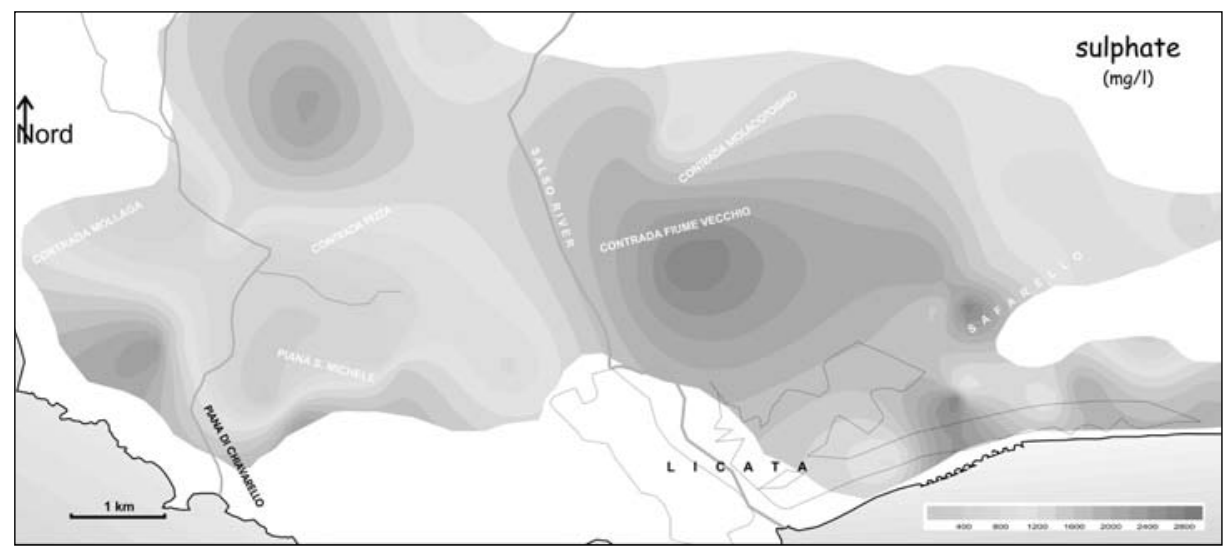

Figure 13. Space distribution of the sulphate $(\mathrm{mg} / \mathrm{l}$; for the location of the monitored wells see Fig. 9).

while the highest values measured east of Licata are likely due to the intrusion of marine salty water. The mixing phenomena between the freshwater from the aquifer and the marine water are confirmed by the occurrence of elevated concentrations in chlorides and sodium up to $4000 \mathrm{mg} / \mathrm{l}$ and larger than $1500 \mathrm{mg} / \mathrm{l}$, respectively.

The chlorides concentration presents oscillation between 29 and $4700 \mathrm{mg} / \mathrm{l}$ with mean values of $1550 \mathrm{mg} / \mathrm{l}$ (Fig. 12). Indeed, there is a proportionally inverse relationship between the chlorides concentration and electrical conductivity (CE) according to the equation:

$$
\mathrm{CE}=0.002 \cdot \mathrm{Cl}-2.57
$$

with a correlation coefficient $\mathrm{r}^{2}=0.71$.

High concentrations of chlorides are located along the coast (> $4000 \mathrm{mg} / \mathrm{l}$ ) and the right hydrographic sector of the Salso River. They are due to widespread phenomena of saline intrusion as confirmed by a sodium content of 1853 $\mathrm{mg} / \mathrm{l}$ in the same areas.
The magnesium $(\mathrm{Mg})$ ranges between 0.2 and $602 \mathrm{mg} / \mathrm{l}$, with an average value of $180 \mathrm{mg} / \mathrm{l}$, while the mean concentration in calcium $(\mathrm{Ca})$ is $593 \mathrm{mg} / \mathrm{l}$, with variations between 66.5 and 1544 $\mathrm{mg} / \mathrm{l}$.

The sulphate generally presents high concentrations across the plain of Licata with a mean value equal to $1530 \mathrm{mg} / \mathrm{l}$; while the lowest values $(<1000 \mathrm{mg} / \mathrm{l})$ are observed in the western sector of the plain. This high values are primarily associated with the intense farming activities and secondarily with the chemical composition of the sediments hosting the aquifer (Fig. 13).

The measured nitrates are mainly derived from agricultural activity and show an average value of $149 \mathrm{mg} / \mathrm{l}$. It is worth to note that the samples were collected during the final phase of the picking period of the agricultural products (Fig. 14).

The index of the sodium absorption ratio (SAR) shows changes between 2 and 15 with a mean value equal to 6.2 . In about $50 \%$ of the 

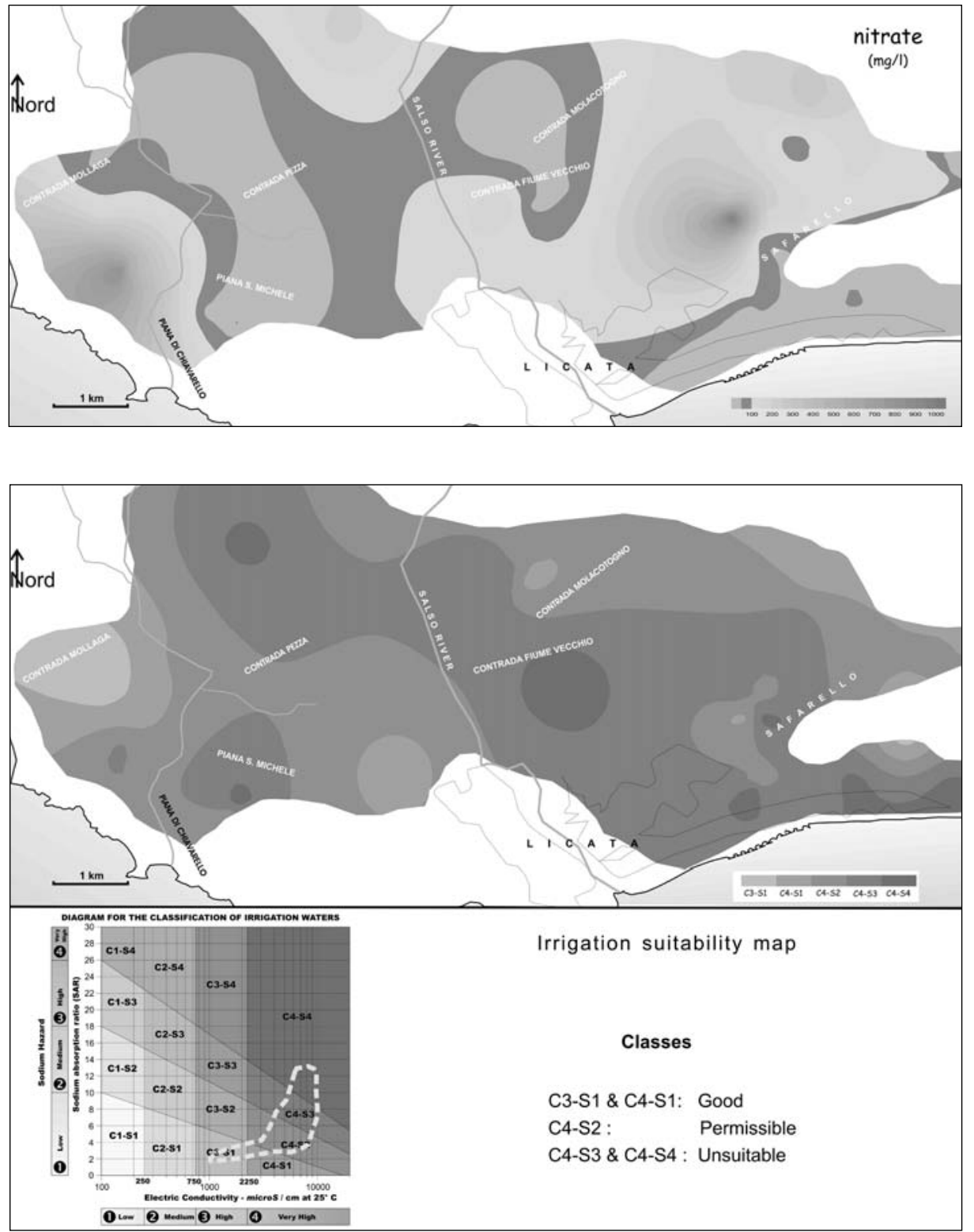

Figure 14. Space distribution of the nitrates $(\mathrm{mg} / \mathrm{l}$; for the location of the monitored wells see Fig. 9).
Figure 15. Irrigation suitability map and relative diagram. samples, this index has values between 8 and 12 (Fig. 15), therefore emphasizing the occurrence of C3-S1 and C4-S1 water categories in the north and east of the investigated area, respectively. In contrast, in the central sector the occurrence of C4-S2, C4-S3 and C4-S4 water categories indicate an underground resource not suitable for irrigation purposes.

\section{Concluding remarks}

Fresh groundwater supplies in many coastal aquifers throughout the world are threatened by natural and anthropogenic causes. The present research allowed to emphasize the behaviour of the coastal aquifers, characterised by an important lithological heterogeneity, where the palaeogeographic evolution of the last millennia, like the formation of the saline and the strong human activities have stressed the underground water system to a critical point thus generating a disequilibrium in the delicate zone represented by the fresh-to-salty waters interface. In semiarid regions, such variations of the hydraulic balance parameters are even more in- 
fluencing because they can accelerate both the degradational processes affecting the natural water resources with catastrophic consequences on the natural ecosystems and the desertification risk of large areas.

As a final comment and suggestion for a sustainable management of fresh groundwater resources in these coastal regions, a tight collaboration between water users and authorities and all the stakeholders in general should be considered a obliged approach to the problem. It is thus concluded that only based on a continuous monitoring of the salinization process it will be possible to provide a better management of the water resources in coastal areas.

\section{Acknowledgment}

The author wish to express her gratitude to Odysseas Christou (director of Geoinfo, Thessaloniki, Greece) and professor C. Vaccaro (University of Ferrara) for the fruitful discussions; also, to Municipality of Licata and "Assessorato Agricoltura e Foreste" of Licata for the support during the campaign.

The work, in the Licata plain, has been supported by MIUR - RIADE project.

\section{References}

Amore C., Geremia F., Randazzo G. 2002. Historical evolution of the Salso River mouth with respect to the Licata harbour system (Southern Sicily, Italy). In: Gomes F.V. et al. (eds.): Littoral 2002: $6^{\text {th }}$ International Symposium Proceedings: "A multi-disciplinary Symposium on Coastal Zone Research, Management and Planning". Porto, 22-26 September 2002, 2, 253-260.

Appelo C.A.J., Geirnaert W. 1983. Processes accompanying the intrusion of salt water. Geol. Appl. Hydrogeol. 18-II, 29-40.

Back W. 1966. Hydrochemical facies and groundwater flow patterns in the northern part of Atlantic coastal plain. US Geol. Surv. Pap. 498-A.

Balasha-Jalon consultans 1992. Impact of Kouris dam on the Akrotiri aquifer. Annex 2, Department of Water Development, Haifa (report).

Barrow E., Semenov M.A. Hulme M. 1995. Construction of site-specific scenarios. In: Harrison R.A., Butterfield R.E., Downing T.E.: Climate Change and Agriculture in Europe. Assessment of Impacts and Adaptations. Research Report 9, 30-50. Oxford Environmental Change Unit, University of Oxford.

Boronina A., Renard P., Balderer W., Stichler W. 2005. Application of tritium in precipitation and in groundwater of the Kouris catchment (Cyprus) for description of the regional groundwater flow. Applied Geochemistry, 20, 1292-1308.
Brandt C.J., Thornes J.B. 1997. Mediterranean desertification and land use. Journal of Hydrology, Brandt C.J., Thornes J.B. (eds.), 201 (1-4), 1-389.

Brandt C.J., Thornes J.B. (eds.) 1996. Mediterranean desertification and land use. Wiley \& Sons, London.

Brandt J. 2005.Desertification information system to support National Action Programmes in the Mediterranean (DISMED). DIS4ME, Desertification Indicator System for Mediterranean Europe (http://dataservice.eea.europa.eu/dataservice/metadetails.asp?id=635).

Calvache M.L., Pulido-Bosch A. 1997. Effect of geology and human activity on the dynamics of salt-water intrusion in three coastal aquifers in southern Spain. Environmental Geology, Sci 30(3/4):215-223.

Cubasch U., von Storch H., Waszkewitz J., Zorita E. 1996. Estimates of climate change in southern Europe derived from dynamical climate model output. Clim. Res., 7, 129-149.

Dazy J., Drogue C., Charmanidis Ph., Darlet Ch. 1997. The influence of marine inflows on the chemical composition of groundwater in small islands: the example of the Cyclades (Greece). Environmental Geology, Sci 31(3/4):133-141.

Edmunds W.M., Darling W.G., Kinniburgh D.G. 1988. Solute profile techniques for recharge estimation in semi-arid and arid terrain. In: Simmers, I. (ed.): Estimation of Natural Groundwater Recharge, Reidel, Dordrecht, Holland, 139-157.

Ergil M. 2000. The salination problem of the Guzelyurt aquifer, Cyprus. Wat. Res., Vol. 34, N. 4, 1201-1214.

Giorgi F., Fransisco R. 2000. Evaluating Uncertainties in the Prediction of Regional Climate Change, Geophys. Res. Lett., 27 (9), 1295-1298.

Gomis-Yagues V., Boluda-Botella F., Ruiz-Bevià F. 2000. Gypsum precipitation/dissolution as an explanation of the decrease of sulphate concentration during seawater intrusion. Journal of Hydrology, 228, 48-55.

Hem J.D. 1978. Study and interpretation of the chemical characteristics of natural water. 3 nd edition U. S. Geological Survey, Water Supply, paper 1473, 365 pp.

Hill J., Stellmes M., Udelhoven Th., Röder A., Sommer S. 2008. Mediterranean desertification and land degradation: Mapping related land use change syndromes based on satellite observations. Global and Planetary Change, 64 (3-4), 146-157.

Howard Humphreys \& Sons 1972. The Akrotiri Project: Agriculure v. 3; Irrigation and drainage, v. 6; Economics, v. 7; London, 1972 (report).

Hydrological Year Book of Cyprus 1984. Cyprus Water Development Department, Nicosia.

Iacovides S.J. 1970. Akrotiri feasibility study, Department of water Development, Nicosia.

Iacovides S.J., Georgiou P., Christodiulides A. 1982. Southern Conveyor Project, Feasibility Study, v. 3, Groundwater Resources, Department of water Development, Nicosia. 
IPCC 2001. Climate Change 2001. The Scientific Basis, Contribution of Working Group I to the Third Assessment Report of the Intergovernmental Panel on Climate Change, Houghton J.T., Ding Y., Griggs D.J., Noguer M., van der Linden P.J., Dai X., Maskell K., Johnson C.A. (eds.), Cambridge Univ. Press, Cambridge, UK, 881 pp.

Kallioras A., Pliakas F., Diamantis I. 2006. Conceptual model of a coastal aquifer system in northern Greece and assessment of saline vulnerability due to seawater intrusion conditions Environ. Geol., 51:349-361.

Karas J.H.W. 1998. Climate Change and the Mediterranean Region. Executive summary of GreenPeace (http://www.greenpeace.org/ climate/kimpacts/fulldes ert. html).

Kok K., Rothmanc D.S., Patel M. 2006. Multi-scale narratives from an IA perspective. Part I. European and Mediterranean scenario development, Futures, 38, 261-284.

Lambrakis N. 1997. The impact of urbanization of Malia coastal area (Crete) on groundwater quality. Environmental Geology, Sci 36, 87-92.

Lambrakis N., Kallergis G. 2001. Reaction of subsurface coastal aquifers to climatic and land use changes in Greece: modelling of groundwater refreshening patterns under natural recharge condition. Journal of Hydrology, 245:19-31.

Lawrence A.R., Lloyd J.W., Marsh J.M. 1976. Hydrochemistry and groundwater mixing in part of the Lincolnshire limestone aquifer, England, Ground Water, 14, 12-20.

Lawrence F.W., Upchurch S.B. 1982. Identification of recharge areas using geochemical factor analysis. Groundwater, 20, 680-687.

Lloyd J.W., Heathcote J.A. 1985. Natural inorganic hydrochemistry in relation to groundwater. Oxford University press, New York, 296 pp.

Lozano E., Coleto C., Manzano M., Custodio E. 2002. Saline water in the coastal area of the national park of Donana (SW of Spain) in absence of saline water intrusion. $17^{\text {th }}$ Salt Water Intrusion Meeting, Delft, The Netherlands, 6-10 May 2002, 238-248.

Matthess G. 1982. The properties of groundwater. John Wiley \& Sons, New York, 213 pp.

Mazi K., Koussis A.D., Restrepo P.J., Koutsoyiannis D. 2004. A groundwater-based, objective-heuristic parameter optimisation method for a precipitation-runoff model and its application to a semi-arid basin. Journal of Hydrology, 290 (3-4), 243-258.

Mitchell T., Hulme M. 2000. A country-by-country analysis of past and future warming rates. Tyndall Centre Internal Report 1, November, UEA, Norwich, UK, 6 pp. (http://www.tyndall.uea.ac.uk/main.htm).

Morell I., Gimènez E., Esteller M.V. 1996. Application of principal components analysis to the study of salinization on the Castellon Plain (Spain). The Science of the Total Environment, 177, 161-171.
Oude Essink G.H.P. 2001. Improving fresh groundwater supply - problems and solutions, Ocean Coast. Manage. 44, 429-449.

Palutikof J.P., Trigo R.M., Adcock S.T. 1996. Scenarios of Future Rainfall over the Mediterranean: is the Region Drying?, Proceedings of Mediterranean Desertification, Research Results and Policy Implications, Crete, Greece, 20 October to 1 November 1996, 1, 33-39.

Palutikof J.P., Wigley T.M.L. 1996. Developing climate change scenarios for the Mediterranean Region, In: Jeftic L., Milliman J.D., Sestini G. (eds.). Climatic Change and the Mediterranean, UNEP, 1, 27-56, Edward Arnold, London.

Petalas C.P., Diamantis I.B. 1999. Origin and distribution of saline groundwaters in the upper Miocene aquifer system, coastal Rhodope area, northeastern Greece. Hydrogeol J. 7(3):305-316.

Piper A.M. 1944. A graphical procedure in the geochemical interpretation of water analyses. Transactions, American Geophysical Union, 25, 914-923.

Plummer L.N., Back W. 1980. The mass balance approach: application to interpreting the chemical evolution of hydrologic systems. American Journal of Sciences, 280:130-142.

Puigdefàbregas J., Mendizabal T. 1998. Perspectives on desertification: western Mediterranean. Journal of Arid Environments, 39, 209-224.

Puigdefábregas J., Mendizabal T., 1998. Perspectives on deserti.cation: western Mediterranean. Journal of Arid Environments, 39, 209-224.

Pulido-Bosch A., Sanchez-Martos F., Navarrete F., Martinez-Vidal J.L. 1992. Groundwater problems in a semiarid area. Environmental Geology, Sci., 20(3):195-205.

Qahman K., Larabi A. 2006. Evaluation and numerical modeling of seawater intrusion in the Gaza aquifer (Palestine). Hydrogeology Journal, 14(5), 713-728.

Rapti-Caputo D. 2005. Geochemical characterization of the Piana di Licata (Agrigento) alluvial aquifer. Giornale di Geologia Applicata, 2, 436-444.

Regione Siciliana - Assessorato Territorio e Ambiente 2002. Relazione sullo stato dell'ambiente della Sicilia. Suolo e sottosuolo (Palermo: Regione Siciliana).

Revelle R. 1941. Criteria for recognition of seawater in groundwaters. Trans. Amer. Geophysical Union 22, 593-597.

Roda C. 1971. Origine della salinità delle acque del Fiume Salso o Imera Meridionale. Bollettino dell'Accademia Gioenia di Scienze Naturali, 10, 471-530.

T.A.Y. database, Department of Water Development, Groundwater Resources, Nicosia.

Tulipano L., Fidelibus M.D. 2002. Mechanisms of groundwater salinization in a coastal karstic aquifer subject to overexploitation. 17th Salt Water Intrusion Meeting, Delft, The Netherlands, 6-10 May 2002, 39-49.

UNESCO 1987. Groundwater problems in coastal areas. Unesco, Belgium. 